\title{
AOR
}

Selected Papers of \#AolR2021:

The 22nd Annual Conference of the

Association of Internet Researchers

Virtual Event / 13-16 Oct 2021

\section{RIP IT UP AND START AGAIN. PIRACY, REMIX AND CO-OPTION IN THE MEDIA INDUSTRY}

\author{
Michelle Phan \\ Simon Fraser University \\ Alessandro Delfanti \\ University of Toronto
}

Media workers use radical remix techniques to produce content for the mainstream media industries. Be it wanna-be influencers remaking the latest viral video on TikTok, videomakers producing dozens of rip-o-matic clips that will constitute the storyboard for TV ads, or writers churning out pieces in content farms in the hope they land on a newspaper, the media industry outsources work to masses of people who use piracy and remix to produce content based on scissor reels composed from existing audio, textual and visual materials. These forms of labour amount to a renewed commodification of media piracy and remix cultures rather than a form of resistance (Johns 2009; Mueller 2019).

These examples are also related to the endemic precarity of the media industry. Among the many who produce content, only a fortunate few will ever be able to monetize their labour. In the meantime, the media industry is positioned to capture the value of this new remix culture downstream. In a sense this is nothing new: the whole history of the cultural industry is one of rip-off, from Vivienne Westwood turning Chelsea's street punk style into marketable fashion, to Chiara Ferragni cannibalizing and monetizing her followers' ideas. Yet what we are witnessing today is the institutionalization of these practices. In fact, the broader landscape in which the labour of rip-off and remix takes place is a digital creator economy fostered and controlled by platforms (Kopf 2020). This is most visible in processes of "platformization" of cultural production (Nieborg and Poell 2018) but can be found even beyond the media industry - just think of Shopify and Amazon providing a platform for and profiting from third-party vendors to which manufacturing and marketing are outsourced.

Our analysis of the rapid pace of content production and the modes in which it is coopted into mainstream media industries is rooted in Italian workerist (autonomist) theories of the production of "surplus", that is, capital's struggle to foster creativity while also controlling the workforce and capturing the value it generates (Hardt and Negri 
2004). In the case of remix cultures, the speed of production is contingent on "the integration of the working class within the system", which for early workerist Mario Tronti is "a vital necessity of capitalism" (Tronti 1962). To fulfill this necessity, creative labour is fostered, datafied and quantified into order to be made productive. For workerists, workers do wield power in the liminal space generated by technologies, and capital must continuously adjust to the ever-changing social and economic landscape in which it operates. This generates tensions. How do you preserve the production of surplus typical of the openness of the creative process while at the same time controlling masses of workers that are not formally employed and capturing the value they generate? For instance, workers' tacit knowledge represents an obstacle to capital's rapid expansion, so it must be codified through forms of algorithmic commodification (Cohen 2015, p. 103).

Here we stress two core tactics used by capital to control creative workers: intellectual property rights and a culture of entrepreneurialism. Media workers who produce rip-off content, say a rip-o-matic video, do so by cutting and pasting existing content from video sharing platforms like YouTube. Freelance jobs for these can be found on platforms such as Fiverr. The copyright that protects content does not prevent them from producing a remixed video as long as it is used internally by the major advertising agencies that commission rip-o-matics. Rather, copyright modulates workers' ability to monetize their labour: only one of the dozens of rip-o-matic videos commissioned to precarious creative workers will eventually be used as the cinematic blueprint for the final commercial, whose copyright will reside with the agency. Intellectual property thus allows agencies to keep the upper hand and control the content created by the independent contractors they employ. Under these conditions, the fluid relation between piracy and copyright, between legal and illegal practices, contributes to multiplying precarity in the sector. Entrepreneurialism is at play too. As they spend sleepless nights cutting and pasting videos to create rip-o-matics, mostly white young male freelance media workers perform a mode of masculinity typical of the era of tech entrepreneurialism in which "subcontracting occurs at an informal rather than formal level, and the pressure workers face to constantly acquire new employment perfectly align with the neoliberal emphasis on the entrepreneurial self" (Mueller 2019, p. 19).

TikTok presents similar challenges. The video-sharing social network service is a widely popular platform that utilizes pastiche, satire, and replication across a series of genres. The platform's users rely on rip-off and remix techniques to create new cultural products, but only the labour of a select few is recognized, for instance through TikTok's newly instituted Creator Fund. Here, the significance of rip-off labour is magnified through the competition for the accumulation of followers. TikTok creators must rely on forms of "aspirational labour" documented in the social media industry (Duffy 2017), as they produce unpaid cultural content with the hope of eventual pay off through sponsorships or monetization. In the meantime, the platform has become one of the most valuable social media companies (at \$250B in Spring 2021).

Finally, remix labour is not race-neutral. For instance, the monetization of creative labour increases the gap between the highest paid influencers and the ones who are censored for posting Black Lives Matter content (Shead, 2020). In response to this backlash, TikTok introduced a Black Creatives incubator program (2021). The 
commodification of Black cultural labour is not novel. Historically, groups such as Public Enemy and Run DMC popularized remix culture through the use of "sampling [that] introduced the acts of copying, cutting, and mixing to everyday culture" (De Kosnik 2019, p. 156-157). The ethos of remix culture hinges on this very idea.

In sum, the imperative of consistent cultural production hinges on piracy and remix as chief sources of value and wealth that "must be jealously held to secure competitive advantage." (Mueller 2019, p. 21). To understand these modes of production, we need to focus on the tactics used to codify and commodify creative labour while also devaluing the work 'from below' of creative workers. An old tension is at play. As an autonomous form of bottom-up reappropriation, the social practice of rip-off has subversive potential. As an activity fostered and commodified by capital, it obscures the power of precarious creative workers while securing their participation in value production within the contemporary digital media landscape.

\section{References}

Cohen, N. (2015). From Pink Slips to Pink Slime: Transforming Media labour in a Digital Age. The Communication Review 18(2), pp. 98-122.

De Kosnik, A. (2019). Why It Matters that Black Men and Queer Women Invented Digital Remix Culture. JCMS: Journal of Cinema and Media Studies 59(1), pp. 156-163.

Duffy, B. E. (2017). (Not) Getting Paid to Do What You Love: Gender, Social Media, and Aspirational Work. Yale University Press.

Hardt, M. And Negri, A. (2004) Multitude: War and Democracy in the Age of Empire. Penguin Books.

Johns, A. (2009). Piracy: The Intellectual Property Wars from Gutenberg to Gates. University of Chicago Press.

Kopf, S. (2020). "Rewarding Good Creators": Corporate Social Media Discourse on Monetization Schemes for Content Creators. Social Media + Society 6(4).

Mueller, G. (2019). Media Piracy in the Cultural Economy: Intellectual Property and labour under Neoliberal Restructuring. Routledge.

Nieborg, D. B., \& Poell, T. (2018). The Platformization of Cultural Production: Theorizing the Contingent Cultural Commodity. New Media \& Society 20(11), pp. 4275-4292.

Shead, S. (2020, June 2). TikTok Apologizes after Being Accused of Censoring \#BlackLivesMatter Posts. CNBC.

Tronti, M. (1962) La fabbrica e la società. Quaderni Rossi, 2.

TikTok. (2021, January 13). Introducing the TikTok for Black Creatives Incubator Program. TikTok Newsroom. 